\title{
A Determinant Analysis of Stunting Prevalence on Under 5-Year-Old Children to Establish Stunting Management Policy
}

\author{
Diah Mutiarasari ${ }^{1 *}$, Miranti Miranti ${ }^{1}$, Yuli Fitriana ${ }^{2}$, David Pakaya ${ }^{2}$, Puspita Sari ${ }^{3}$, Bohari Bohari ${ }^{4}$, Muhammad Sabir ${ }^{5}$, \\ Rosa Dwi Wahyuni ${ }^{6}$, Ryzqa Ryzqa ${ }^{7}$, Veni Hadju ${ }^{8}$ \\ ${ }^{1}$ Department of Community Health, Public Health Science, Faculty of Medicine, Universitas Tadulako, Palu, Indonesia; \\ ${ }^{2}$ Department of Histology, Faculty of Medicine, Universitas Tadulako, Palu, Indonesia; ${ }^{3}$ Department of Anatomical Pathology, \\ Faculty of Medicine, Universitas Tadulako, Palu, Indonesia; ${ }^{4}$ Department of Nutrition, Faculty of Medicine, Universitas Sultan \\ Ageng Tirtayasa, Indonesia; ${ }^{5}$ Department of Microbiology, Faculty of Medicine, Universitas Tadulako, Palu, Indonesia; ${ }^{6}$ Department \\ of Clinical Pathology, Faculty of Medicine, Universitas Tadulako, Palu, Indonesia; ${ }^{7}$ Provincial Health Office of Central Sulawesi, \\ Palu, Indonesia; ${ }^{8}$ Department of Nutrition Science, Faculty of Public Health, Universitas Hasanuddin, Makassar, Indonesia
}

Edited by: Sasho Stolesk Citation: Mutiarasari D, Miranti M, Fitriana Y, Pakaya D, Sari P, Bohari B, Sabir M, Wahyuni RD, Ryzqa R, Hadju V. 5-Year-Old Children to Establish Stunting Management 5-Year-Old Children to Establish Stunting Management
Policy. Open Access Maced J Med Sci. 2021 Jan 19 9(B):79-84 https://doi.org/10.3889/oamjms.2021.5622 Keywords: Stunting; Children; Health care Correspondence: Diah Mutiarasari, Department of Community Health, Public Health Science, Faculty of Mdicine, Universitas Tadulako, Palu, Indonesia. . Received: 09-Dec-2020 Accepted: 09-Jan-2021 Copyright: ๑ 2021 Diah Mutiarasari, Miranti Miranti, Yuli Fitriana, David Pakaya, Puspita Sari, Bohari Bohari, Muhammad Sabi Rosa Dwi Wahyuni, Ryzqa Ryzqa, Veni Hadju Funding: This study was supported by the Medical Faculty of Universitas Tadulak Competing Interest: The authors have declared that no Open Access: This is an open-access article distributed under the terms of the Creative Commons Atributionunder the terms of the Creative Commons Attribution-

\begin{abstract}
OBJECTIVE: In Indonesia, stunting is a nutritional problem that is a threat to the growth and development of toddlers since the beginning of life. The total stunting of children under-five in 2018 in Palu city was $30.8 \%$. Hence, it is necessary to strengthen the system that supports the determination of continued government policies in achieving a reduction in the incidence of stunting.

METHODS: A case control with research subjects totaling 520 toddlers. The sampling technique used was proportional stratified random sampling at all Puskesmas Kota Palu.

RESULTS: There is a multifactorial relationship between knowledge variables $(p=0.019)$, children have been sick $(p=0.000)$, mother's height $(p=0.050)$, and mother's education $(p=0.000)$ against the incidence of stunting. Low knowledge has a chance of 1.581 times and the status of the child having been sick has a chance of 9.166 times the incidence of stunting

CONCLUSION: Multiple factors play a role in causing stunting in the city of Palu. Analysis of factors related to the incidence of stunting in children under-five in the working area of the Palu City Health Center is considered necessary in supporting the government in determining policies to tackle stunting problems.
\end{abstract}

\section{Introduction}

Globally, in 2017, there were 151 million of under 5 -year-old children (22\%) who experienced stunting (their growth is below the average growth for their age). About three-fourth of those children live in Southeast Asia or Africa. High level of stunting has negative impact on nation's development as its related to morbidity risk and child's mortality, learning capacity of the children, and non-communicable diseases in later stage of life. In 2017, about 51 million under 5-year-old children (7.5\%) experienced wasting (too light for their body height), whereas 38 million of under 5 -year-old children (5.6\%) were obese (too heavy for their body height) [1].

Based on the nutrition status monitoring for the past 3 years, shortness has the highest prevalence than other nutrition-related cases. The prevalence of shortness or stunting has been steadily increasing from $27.5 \%$ in 2016 to $29.6 \%$ in 2017 [2]. Compared to other
ASEAN countries, stunting prevalence in Indonesia is categorized into high prevalence, together with Cambodia and Myanmar [3]. Out of 556 million of under 5 -year-old children in developing countries, 178 million of them (32\%) are short and 19 million of them are severely underweight $(<-3 S D)$ and 3.5 million of these children die each year.

Based on the data above, a study was to analyze determinant factors of stunting prevalence in under 5 -year-old children in Palu city health-care centers to support government in creating stunting reduction policy.

\section{Methods}

This was a case-control study on factors that determine stunting prevalence. There were a total of 
520 toddlers involved in this study based on the inclusive and exclusive criteria. Samples for this study were determined using proportional stratified random sampling in 13 health-care centers (Puskesmas) in Palu city. This study was implemented in several health-care centers (Puskesmas) in Palu city of Central Sulawesi and was implemented from June to August 2020. The variables in this study were stunting, birth weight, exclusive breastfeeding record, immunization record, infectious diseases record, mother's level of education, mother's parenting method, level of family income, number of family members, parents' weight, and residence.

\section{Results}

Table 1 shows that based on univariate analysis of the respondents' characteristic of the age of mother's whose child is affected by stunting; the highest percentage is on mothers age 20-35 years old by 202 respondents $(74.8 \%)$ and the lowest is on $<20$ years old age group by 13 respondents (4.8\%). Similarly, this 20-35 years old mothers have the largest percentage of healthy children by 229 respondents (79\%) and the $<20$ years old group is also the group with smallest number of healthy children by only 16 children $(5.5 \%)$.

Table 1: Characteristics of respondents

\begin{tabular}{|c|c|c|c|c|c|c|}
\hline \multirow{3}{*}{ Characteristics } & \multicolumn{4}{|c|}{ Stunting } & \multirow{2}{*}{\multicolumn{2}{|c|}{ Total }} \\
\hline & \multicolumn{2}{|l|}{ Yes } & \multicolumn{2}{|l|}{ No } & & \\
\hline & $\mathrm{n}$ & $\%$ & $\mathrm{n}$ & $\%$ & $\mathrm{n}$ & $\%$ \\
\hline \multicolumn{7}{|l|}{ Mother's age group (years old) } \\
\hline$<20$ & 13 & 4.8 & 16 & 5.5 & 29 & 5.2 \\
\hline $20-35$ & 202 & 74.8 & 229 & 79.0 & 431 & 77.0 \\
\hline$>35$ & 55 & 20.4 & 45 & 15.5 & 100 & 17.9 \\
\hline \multicolumn{7}{|c|}{ Level of education of the head of family } \\
\hline Uneducated & 7 & 2.6 & 11 & 3.8 & 18 & 3.2 \\
\hline Elementary school & 72 & 26.7 & 42 & 14.5 & 114 & 20.4 \\
\hline Junior high school & 71 & 26.3 & 55 & 19.0 & 126 & 22.5 \\
\hline Senior high school & 103 & 38.1 & 140 & 48.3 & 243 & 43.4 \\
\hline Diploma/tertiary school & 17 & 6.3 & 42 & 14.5 & 58 & 10.5 \\
\hline \multicolumn{7}{|l|}{ Mother's level of education } \\
\hline Uneducated & 8 & 3.0 & 9 & 3.1 & 17 & 3.0 \\
\hline Elementary school & 70 & 25.9 & 63 & 21.7 & 133 & 23.8 \\
\hline Junior high school & 63 & 23.3 & 70 & 24.1 & 133 & 23.8 \\
\hline Senior high school & 106 & 39.3 & 101 & 34.8 & 207 & 37.0 \\
\hline Diploma/tertiary school & 23 & 8.5 & 47 & 16.2 & 70 & 12.5 \\
\hline \multicolumn{7}{|l|}{ Head of family's employment status } \\
\hline Unemployed & 4 & 1.5 & 3 & 1.0 & 7 & 1.3 \\
\hline Student & 1 & 0.4 & 1 & 0.3 & 2 & 0.4 \\
\hline Government employee & 8 & 3.0 & 21 & 7.2 & 29 & 5.2 \\
\hline Non-government employee & 27 & 10.0 & 34 & 11.7 & 61 & 10.9 \\
\hline Businessman & 116 & 43.0 & 125 & 43.1 & 241 & 43.0 \\
\hline Others & 114 & 42.2 & 106 & 36.6 & 220 & 38.3 \\
\hline \multicolumn{7}{|l|}{ Mother's employment status } \\
\hline Unemployed & 198 & 73.3 & 218 & 75.2 & 416 & 74.3 \\
\hline Student & 1 & 0.4 & 3 & 1.0 & 4 & 0.7 \\
\hline Government employee & 1 & 0.4 & 6 & 2.1 & 7 & 1.3 \\
\hline Non-government employee & 5 & 1.9 & 9 & 3.1 & 14 & 2.5 \\
\hline Businesswoman & 27 & 10.0 & 36 & 124 & 63 & 11.3 \\
\hline Others & 38 & 14.1 & 18 & 6.2 & 56 & 10.0 \\
\hline \multicolumn{7}{|l|}{ Mother's height $(\mathrm{cm})$} \\
\hline$<150$ & 111 & 41.1 & 96 & 331 & 207 & 37.0 \\
\hline$\geq 150$ & 159 & 58.9 & 194 & 66.9 & 353 & 63.0 \\
\hline \multicolumn{7}{|l|}{ Family economic status } \\
\hline$<$ UMK & 222 & 82.2 & 231 & 79.7 & 453 & 80.9 \\
\hline$\geq$ UMK & 48 & 17.8 & 49 & 20.3 & 107 & 19.1 \\
\hline \multicolumn{7}{|l|}{ Number of family member (people) } \\
\hline $1-4$ & 50 & 18.5 & 67 & 23.1 & 117 & 20.9 \\
\hline$\geq 4$ & 220 & 81.5 & 223 & 76.9 & 443 & 79.1 \\
\hline \multicolumn{7}{|l|}{ Residence status } \\
\hline Temporary shelter & 13 & 4.8 & 2 & 0.7 & 15 & 2.7 \\
\hline Non-temporary shelter (house) & 257 & 95.2 & 288 & 99.3 & 545 & 97.3 \\
\hline Total & 270 & 100 & 290 & 100 & 560 & 100 \\
\hline
\end{tabular}

Table 2 shows that according to sex group, $53.3 \%$ of male toddlers' (144 respondents) were affected by stunting. Meanwhile, 160 female toddlers $(55.2 \%)$ were not affected by stunting. This table also describes that children age 0-23 months old are the most vulnerable age group to stunting, where 132 respondents (48.9\%) were affected by stunting. Meanwhile, the largest age group unaffected by stunting is the 37-60 months old group, where 124 respondents $(42.8 \%)$ were unaffected.

Table 2: Toddler's characteristics

\begin{tabular}{|c|c|c|c|c|c|c|}
\hline \multirow[t]{3}{*}{ Variable } & \multicolumn{4}{|c|}{ Stunting } & \multirow{2}{*}{\multicolumn{2}{|c|}{ Total }} \\
\hline & \multicolumn{2}{|l|}{ Yes } & \multicolumn{2}{|l|}{ No } & & \\
\hline & $n$ & $\%$ & $\mathrm{n}$ & $\%$ & $n$ & $\%$ \\
\hline \multicolumn{7}{|l|}{ Sex } \\
\hline Female & 126 & 467 & 160 & 55.2 & 286 & 51.1 \\
\hline Male & 144 & 53.3 & 130 & 44.8 & 274 & 48.9 \\
\hline \multicolumn{7}{|c|}{ Age group (months) } \\
\hline $0-23$ & 132 & 48 & 78 & 26.9 & 210 & 37.5 \\
\hline $24-36$ & 60 & 22.2 & 88 & 30.3 & 148 & 26.4 \\
\hline $37-60$ & 78 & 28.9 & 124 & 42.8 & 202 & 36.1 \\
\hline
\end{tabular}

Table 3 shows that portrays $p=0.019(p \leq s 0.05)$ to reject $\mathrm{HO}$, which means that there is a correlation between knowledge level and stunting incidence. There are 193 respondents $(71.5 \%)$ with stunting who have sufficient knowledge, whereas 232 respondents (80\%) have sufficient knowledge and healthy baby. Further, on toddler's has ever sick indicator shows a result of $p=0.000$ ( $p \leq 0.05)$, which means that toddlers who have been sick have a significant correlation with the incidence of stunting. This means that there is a correlation between stunting incidence and sickness record of children. There are 265 respondents (98.1\%) who have ever sick and affected with stunting, whereas 246 toddlers (84.8\%) have ever sick but they have normal growth.

Table 3: Research variable

\begin{tabular}{|c|c|c|c|c|c|c|c|}
\hline \multirow[t]{3}{*}{ Variable } & \multicolumn{4}{|c|}{ Stunting } & \multirow{2}{*}{\multicolumn{2}{|c|}{ Total }} & \multirow[t]{3}{*}{$\mathrm{p}$} \\
\hline & \multicolumn{2}{|l|}{ Yes } & \multicolumn{2}{|l|}{ No } & & & \\
\hline & $\mathrm{n}$ & $\%$ & $\mathrm{n}$ & $\%$ & $\mathrm{n}$ & $\%$ & \\
\hline \multicolumn{8}{|l|}{ Knowledge } \\
\hline Insufficient & 77 & 28.5 & 58 & 20.0 & 135 & 24.1 & \multirow[t]{2}{*}{0.019} \\
\hline Sufficient & 193 & 71.5 & 232 & 80.0 & 524 & 75.9 & \\
\hline \multicolumn{8}{|c|}{ Toddler's was never sick (sickness record) } \\
\hline Yes & 265 & 98.1 & 246 & 84.8 & 511 & 91.3 & \multirow[t]{2}{*}{0.000} \\
\hline No & 5 & 1.9 & 44 & 15.2 & 49 & 8.8 & \\
\hline \multicolumn{8}{|c|}{ Colostrum administration } \\
\hline $\mathrm{N}$ & 34 & 12.6 & 29 & 10.0 & 63 & 11.3 & \multirow[t]{2}{*}{0.332} \\
\hline Yes & 236 & 87.4 & 261 & 90.0 & 497 & 88.8 & \\
\hline \multicolumn{8}{|c|}{ Family economic status } \\
\hline$<$ UMK & 222 & 82.2 & 231 & 797 & 453 & 80.9 & \multirow[t]{2}{*}{0.444} \\
\hline$\geq$ UMK & 48 & 17.8 & 49 & 20.3 & 107 & 19.1 & \\
\hline \multicolumn{8}{|c|}{ Number of family members (people) } \\
\hline $1-4$ & 50 & 18.5 & 67 & 23.1 & 117 & 20.9 & \multirow[t]{2}{*}{0.182} \\
\hline$\geq 4$ & 220 & 81.5 & 223 & 76.9 & 443 & 79.1 & \\
\hline \multicolumn{8}{|c|}{ Mother's height $(\mathrm{cm})$} \\
\hline$<150$ & 111 & 41.1 & 96 & 33.1 & 207 & 37.0 & \multirow[t]{2}{*}{0.050} \\
\hline$\geq 150$ & 159 & 58.9 & 194 & 66.9 & 353 & 63.0 & \\
\hline \multicolumn{8}{|c|}{ Father's level of education } \\
\hline Low & 150 & 55.6 & 108 & 37.2 & 258 & 46.1 & \multirow{2}{*}{0.448} \\
\hline High & 120 & 44.4 & 182 & 62.8 & 302 & 53.9 & \\
\hline \multicolumn{8}{|c|}{ Mother's level of education } \\
\hline Low & 141 & 52.2 & 142 & 49.0 & 283 & 50.5 & \multirow[t]{2}{*}{0.000} \\
\hline High & 129 & 47.8 & 148 & 51.0 & 277 & 49.5 & \\
\hline \multicolumn{8}{|c|}{ Breastfeeding record } \\
\hline No & 24 & 8.9 & 15 & 5.2 & 39 & 7.0 & \multirow[t]{2}{*}{0.084} \\
\hline Yes & 246 & 91.1 & 275 & 94.8 & 521 & 93.0 & \\
\hline \multicolumn{8}{|c|}{ Immunization record } \\
\hline No & 5 & 1.9 & 11 & 3.8 & 16 & 2.9 & \multirow[t]{2}{*}{0.168} \\
\hline Yes & 265 & 98.1 & 279 & 96.2 & 544 & 97.1 & \\
\hline
\end{tabular}

Table 4 shows that the $p$ value of knowledge variable is significant by $0.026(p<0.05)$. Thus, there is a significant influence of knowledge on stunting 
Table 4: Multivariate analysis

\begin{tabular}{|c|c|c|c|c|c|c|c|c|}
\hline \multirow[t]{2}{*}{ Variables in the equation } & \multirow[t]{2}{*}{$\mathrm{B}$} & \multirow[t]{2}{*}{ S.E. } & \multirow[t]{2}{*}{ Wald } & \multirow[t]{2}{*}{$\mathrm{df}$} & \multirow[t]{2}{*}{ Sig. } & \multirow[t]{2}{*}{$\operatorname{Exp}(B)$} & \multicolumn{2}{|c|}{ 95\% C.I. for EXP(B) } \\
\hline & & & & & & & Lower & Upper \\
\hline \multicolumn{9}{|l|}{ Step $1^{\mathrm{a}}$} \\
\hline Knowledge (1) & 0.481 & 0.208 & 5.332 & 1 & 0.021 & 1.617 & 1.075 & 2.432 \\
\hline Mother's level of education (1) & 0.132 & 0.179 & 0.541 & 1 & 0.462 & 1.141 & 0.803 & 1.619 \\
\hline Mother's height (1) & 0.308 & 0.183 & 2.834 & 1 & 0.092 & 1.360 & 0.951 & 1.945 \\
\hline Has (name of the child) ever been sick (1) & 2.208 & 0.482 & 21.006 & 1 & 0.000 & 9.102 & 3.540 & 23.404 \\
\hline Constant & -2.434 & 0.488 & 24.906 & 1 & 0.000 & 0.088 & & \\
\hline \multicolumn{9}{|l|}{ Step $2^{a}$} \\
\hline Knowledge (1) & 0.458 & 0.206 & 4.956 & 1 & 0.026 & 1.581 & 1.056 & 2.365 \\
\hline Mother's height (1) & 0.323 & 0.181 & 3.165 & 1 & 0.075 & 1.381 & 0sss.968 & 1.971 \\
\hline Has (name of the child) ever been sick? (1) & 2.215 & 0.482 & 21.150 & 1 & 0.000 & 9.166 & 3.565 & 23.564 \\
\hline Constant & -2.374 & 0.480 & 24.420 & 1 & 0.000 & 0.093 & & \\
\hline
\end{tabular}

incidence with the determinant coefficient value of 0.458. In addition, the child's sickness record (has she/ he ever been sick) was also a significant variable on stunting incidence. The determinant coefficient for this variable is $0.000(p<0.05)$. Thus, there is a significant influence on the status of the child who has been sick on stunting incidence with the determinant coefficient of 2.215. Further, based on the $\exp (B)$ value, it is known that insufficient knowledge contributes to the stunting incidence by 1.581 times higher than respondents with sufficient knowledge. Next, on the child who has been sick variable (sickness record), it shows that the child who has ever been sick has the $\exp (\mathrm{B})$ value of 9.166. This indicates that a child who has ever been sick is 9.166 times more susceptible to stunting that child who has never been sick.

\section{Discussion}

\section{Level of knowledge}

Preparation of balanced nutritious food is an important factor to increase the nutrition status of a family member. This will only be attained when the family, especially mother, has sufficient knowledge on nutrition. Proper understanding, attitude, and behavior on selection of food materials, food preparation, including food security for family will have a significant impact on stunting prevention [4]. This present study revealed a correlation between level of knowledge and stunting incidence (0.019). Regardless to having a mother with sufficient knowledge, 193 children in this study were still affected with stunting. This finding is consistent with the study by Ni'mah and Nadhroh, 2015, West et al., 2018, which showed that appropriate level of knowledge would minimize the risk of stunting. The nutrition knowledge is not only obtained from school but also from other sources. Puskesmas (health-care center) and Posyandu (integrated healthcare center) are the frontline of nutrition service for expecting mothers and children. These services are not only limited to providing additional nutritious food for expecting mothers and children but also providing information for selection and preparation of healthy and nutritious food products [5].

\section{Child's sickness record}

On variable of child's who has ever been sick, the result is $p=0.000$ ( $p \leq 0.05)$, thus, HO is rejected. This means that there is a correlation between child's sickness record and stunting incidence. This study does not differentiate type of sickness experienced by toddler and stunting incidence. This result supports the result of study by Nkurunziza et al. which indicated that children with stunting were affected with sickness, especially in the early days of after their birth [6]. However, the result of this present study is different from Muldiasman et al. who differentiate types of diseases and their correlation to stunting incidence. In their study, it was revealed that only diarrhea correlates with stunting incidence, whereas cough, fever, and breathing difficulties are not correlated with stunting [7]. Diarrhea correlates with stunting as it causes losses of various nutrition and electrolyte from the body of the toddlers, in addition to reduce the quality of their digestion system [8].

\section{Administration of colostrum}

Colostrum contains vitamins, minerals, and antibodies who are essentials nutrition to prevent stunting. This study exposes that there is no correlation between colostrum administration and stunting incidence $(p=0.332)$. The result is in sync with the study conducted by Torlesse et al. who indicated that there is no association between early breastfeeding initiations that contain colostrum with stunting incidence [9]. This result, however, opposes the result of study conducted by Muldiasman et al. who reported that toddlers who did not receive early breastfeeding initiation with colostrum in it have 1.3 times higher risk of stunting than those who received early breastfeeding initiation [7]. In addition, Kidane also reported that babies who received colostrum have $49 \%$ smaller possibility to experience stunting than those who did not [10]. Various studies have revealed a correlation between stunting incidence and breastfeeding. Nevertheless, a specific description on the strength of this correlation is yet provided [11]. Torlesse et al. reported a moderate correlation between administrations of age-appropriate meals, including exclusive breastfeeding on $0-5$ months old babies, with the reduction of stunting incidence. This indicates that without administration of colostrum on early breastfeeding initiation accompanied by 
age-appropriate meal can prevent stunting on under 5-year-old children [9].

\section{Family economic status}

This study reveals that there is no correlation between family economic status and stunting incidence $(p=0.444)$. The respondents in this study came from various economic backgrounds. This diverse economic background is intended to delimitate respondents, thus, more obtained data are obtained. The result of this present study is different from the findings of $E$ I Kishawi et al. and Ramadhan et al. who reported a correlation between economic status and stunting. However, their studies tend to have similarity in terms of its environment, one was carried out in Gaza strip and the later was conducted in the urban area of Banda Aceh city. The bad economic condition of these two locations will increase stunting prevalence as of their subjects inability to provide nutritious meal for the family [12], [13].

\section{Number of family members}

Number of family members is one of the indicators to determine socioeconomic status in stunting incidence. In this study, it reveals that there is no correlation between number of family members and stunting incidence $(p=0.182)$. Similar result is also reported by Torlesse et al. and Rohmawati and Antika. Number of family members is one of the elements to prevent acute and chronic malnutrition [9], [14]. The larger the family size, the larger the burden of family expense for food. The effect is on the distribution of food for children. Rahmawati et al. and Wicaksono and Harsanti reported results that are different from this study on the correlation between number of family members and stunting incidence [15], [16].

\section{Mother's body height}

Mother's body height genetically influences a child's growth [17]. Black as cited in Faridah found that intrauterine growth failure increases on bad nutritional status and mother's with short height. This causes insufficient intrauterine growth that will further effect the after birth growth and development of the baby [18].

Mother's body height is one of the variables that determine stunting incidence. In this study, mother's height significantly predicts a baby to be affected with stunting $(p=0.050)$. There are 159 respondents whose mother's height is $\geq 150 \mathrm{~cm}$ which are affected with stunting, whereas 194 other respondents whose mother's height is $\geq 150 \mathrm{~cm}$ are not affected with stunting. This result is consistent with the studies by El Kishawi et al. and Mikawati et al. who found that stunting is also influenced by mother's height. Anthropometry is useful in predicting nutritional status of individual related to general evaluation of health. One of the methods is to measure body height. Short body height of the previous generation will be passed down to the next generation during the growth period. This may cause by genetic and non-genetic factors, such as nutrition [12], [19].

\section{Parents' level of education}

Father's level of education does not show a correlation with stunting ( $p=0.448$ ). This result is in contrast with the result of study by Rohmawati and Antika who showed that father's level of education also plays a role on stunting incidence on children. This different result is suspected to the common practice in our community, where direct parenting activities are mostly carried out by mothers and not fathers. Father's level of education influences on the possibility of having better job to provide better income for the family [14].

A study by Dewi and Widari states that parents' level of education has no correlation with stunting incidence in under 2-year-old children in Balen subdistrict of Bojonegoro district. This is because the level of education has no direct influence on stunting incidence. However, there are other factors that may influence stunting incidence. One of the undisputed facts is that mothers who have high level of education will better understand information and can learn to understand appropriate parenting methods and nutrition that are appropriate for under 2-year-old children, thus, the children can have better nutrition status [20].

\section{Mother's age}

This study reveals that the highest percentage of stunting happens in the mother's age 20-35 years old group by $74.8 \%$. The percentage of healthy babies in the same group age is a bit higher by $79 \%$. In their study, Agustiningrum et al. [20] reported that mother's age has no influence on stunting incidence. However, it has more significant influence on their parenting method, in this case, the way they select and prepare meals for their children. In addition, it is also related to psychological readiness of the mothers to accept their pregnancy. Similarly, Wahyuni et al. [17] also reported in their study that the age of expecting mothers influences the intrauterine growth of the baby and in addition to balanced food intake also has a positive impact on baby.

Low level of mother's education influences the family and personal hygiene knowledge, and provision of nutrition [10], [14], [21]. Mother plays an important role that determines the health status of her baby, thus, mother's level of education made her more selective and creative in selecting, preparing, and presenting meals for her baby [22], [23]. A previous study in Burundi has reported that mother with low level of education is 1.6 times riskier to give birth to a stunted child [6]. Low 
level of education is inseparable with low economic level or low family income. Due to this low level of income, large proportion of family budget is allocated for basic necessities like food and less are allocated for education [14].

\section{Employment and family economic status}

Employment and economic status of the parent may contribute to the provision of nutrition needs of the family and access to health services [24]. Parents with no stable jobs will have difficulty to manage their provision of family necessities and, in turn, will be less attentive to the nutrition needs of the child. Hence, children from low-income family, due to their family's lack of ability to provide nutritious meals, tend to be more vulnerable to malnutrition risks. A different result is reported by Dewi and Widari [25] where they reported that there is no correlation between low-income family and stunting incidence. However, larger proportion of stunting children came from low-income family than non-low-income family. Level of family income reflects family ability to provide nutritious meals for their members.

\section{Residence}

Residence or housing is a building the family lives and resides [26]. Personal hygiene of the resident influenced the function of the housing. A poor personal hygiene possesses higher risk for disease transmission through meals prepared and provided for family members, especially children in their growth time. Failure to provide balanced nutritious intake will result in growth failure or stunting, which will influence child's immunity and growth [27].

Studies conducted in India and Ethiopia reported a correlation between stunting and residence condition. A study in Ethiopia was carried out in the southern part of the country, which are mostly rural area with low level of environmental health. In India, a study was carried out in the north, in urban areas with better environmental quality [8], [28].

\section{Toddler's characteristics}

This present study reveals that boys are more vulnerable to stunting than girls. This condition due to differences on feeding practices by the parents [18]. The age of toddlers who are affected with stunting is influenced by mother's condition in the first 1000 days of life, from the fetus up to the baby is 2 years old. This time is a critical window due to at this time brain development or intelligence development and the growth of the body happen at its maximum speed. Thus, when expecting mother is not supplied with balanced and nutritious food, baby does not get exclusive breastfeeding after birth, and nutritious complementary food for breast milk, the child will be more likely to experience stunting. Stunting that happens on 0-2 years old baby and continued up to the baby ages 3-6 years old will have a higher risk for pre-puberty stunting (age 7-9 years old) [29].

\section{Conclusion}

The evidence from this study suggests that knowledge, mother's height, child's sickness record, and mother's level of education are risk factors for stunting incidence in Palu city. Meanwhile, the main risk factors of stunting in Palu city are knowledge, child's sickness record, and mother's body height. Child with sickness record in their early life is 9.166 times more susceptible to stunting than child with no sickness record in their early life. Meanwhile, low level of knowledge is 1.581 times riskier for stunting compared to sufficient knowledge. Taking into consideration these risk factors for stunting in Palu city area, the factors that can be modified are level of knowledge and child's sickness record. Therefore, parents who have or plan to have under 5-year-old children are recommended to increase their knowledge on nutrition intake needed for the children and to maintain their children's health to prevent stunting incidence.

\section{Acknowledgment}

We acknowledge the contribution of all parties involved in this research. We acknowledge the contribution of the Medical Faculty of Universitas Tadulako for funding this study.

\section{References}

1. World Health Organization. World Health Statistics 2017: Monitoring Health for the SDGs Status of the Health-Related SDGs; 2017. p. 29-35.

2. Kemenkes RI. Data dan Informasi Profil Kesehatan Indonesia 2018, Data dan Informasi Profil Kesehatan Indonesia; 2018. https://doi.org/10.22146/bip.13024

3. Bloem MW, dePeeS, Hop LT, Khan NC, LaillouA, Minarto, etal. Key strategies to further reduce stunting in Southeast Asia: Lessons from the ASEAN countries workshop. Food Nut Bull. 2013;34 Suppl 2:8-16. https://doi.org/10.1177/15648265130342s103 PMid:24049992

4. Nadhiroh SR, Ni'mah K. Factors Related to Stunting in Children Med Gizi Indones. 2010;1:13-9. http://dx.doi.org/10.20473/mgi. v10i1.13-19. 
5. West J, Syafiq A, Crookston B, Bennett C, Hasan MR, Dearden K, et al. Stunting-related knowledge: Exploring sources of and factors associated with accessing stunting-related knowledge among mothers in Rural Indonesia. Health. 2018;10(9):1250-60. https://doi.org/10.4236/health.2018.109096

6. Nkurunziza S, Meessen B, van geertruyden JP, Korachais C. Determinants of stunting and severe stunting among Burundian children aged 6-23 months: Evidence from a national crosssectional household survey, 2014. BMC Pediatr. 2017;17(1):176. https://doi.org/10.1186/s12887-017-0929-2

\section{PMid:28743238}

7. Muldiasman M, Kusharisupeni K, Laksminingsih E, Besral B Can early initiation to breastfeeding prevent stunting in 6-59 months old children? J Health Res. 2018;32(5):334-41. https:// doi.org/10.1108/jhr-08-2018-038

8. Batiro B, Demissie T, Halala Y, Anjulo AA. Determinants of stunting among children aged 6-59 months at Kindo Didaye woreda, Wolaita Zone, Southern Ethiopia: Unmatched case control study. PLoS One. 2017;12(12):e0189106. https://doi. org/10.1371/journal.pone. 0189106

PMid:29261680

9. Torlesse H, Cronin AA, Sebayang SK, Nandy R. Determinants of stunting in Indonesian children: Evidence from a cross-sectional survey indicate a prominent role for the water, sanitation and hygiene sector in stunting reduction. BMC Public Health. 2016;16(1):669. https://doi.org/10.1186/s12889-016-3339-8 PMid:27472935

10. Kidane W. Prevalence and predictors of stunting among children of age between 6 to 23 months in four districts of Wolaita Zone, Southern Ethiopia. Health Sci J. 2020;(5):1-7.

11. Beal T, Tumilowicz A, Sutrisna A, Izwardy D, Neufeld LM. A review of child stunting determinants in Indonesia. Matern Child Nutr. 2018;14(4):e12617. https://doi.org/10.1111/mcn.12617 PMid:29770565

12. El Kishawi RR, Soo KL, Abed YA, Muda WA. Prevalence and associated factors influencing stunting in children aged 2-5years in the Gaza Strip-Palestine: Across-sectional study. BMC Pediatr. 2017;17(1):210. https://doi.org/10.1186/s12887-017-0957-y PMid 29268788

13. Ramadhan $\mathrm{MH}$, Salawati L, Yusuf S. Relationship between Mother's High, Social Economy and Zinc Source Intake withStunting who Aged 3-5 Years at Puskesmas Darussalam Kopelma. Jurnal Averrous. 2020;6(1):55-65. https://doi. org/10.29103/averrous.v6i1.2661

14. Rohmawati N, Antika RB. Risk Factors Stunting Incidence in Children Aged 6-36 Months in Jember Regency, $3^{\text {rd }}$ International Nursing Conference; 2017. p. 128-36.

15. Rahmawati NF, Fajar NA, Idris H. Social, economic factors, and utilization of posyandu towards stunting among toddlers of poor families of PKH recipients in Palembang. J Gizi Klinik Indones. 2020;17(1):23. https://doi.org/10.22146/ijcn.49696

16. Wicaksono F, Harsanti T. Determinants of stunted children in Indonesia: A multilevelanalysis at the individual, household, and community levels. Kesmas. 2020;15(1):48-53. https://doi. org/10.21109/kesmas.v15i1.2771

17. Wahyuni C, Mahmudah S. Analysis of the attitudes of fertile aged couples about reproductive health on postponement of pregnancy in Blabak village, Islamic boarding school district, Kediri. 2017;6(2):59-62. https://doi.org/10.30994/sjik.v6i2.10

18. Hanum F, Khomsan A, Masyarakat DG. Correlation of Nutrients Intake and Maternal Height with Nutritional Statusin Children Under Five Years Old. J Gizi Pangan. 2014;9(1):1-6. https://doi. org/10.25182/jgp.2014.9.1.\%25p.

19. Mikawati, Lusiana E, Hasriany. The Relationship between Exclusive Breastfeeding (ASI) and Mother Heightwith Incident Rates Stunting among Child Age 2-5 Years in Barombong Public Health Center, Gowa, Sulawesi Selatan, KnE Life Sci; 2019. p. 558-67. https://doi.org/10.18502/kls.v4i13.5306

20. Agustiningrum T, Rokhanawati D. Hubungan Karakteristik lbu Dengan Kejadian Stunting Pada Balita Usia 24-59 Bulan di Wilayah Kerja Puskesmas Wonosari I. Indonesia: Universitas 'Aisyiyah Yogyakarta; 2016. p. 1-6. https://doi.org/10.20473/ amnt.v1i3.6251

21. Titaley CR, Ariawan I, Hapsari D, Muasyaroh A, Dibley MJ. Determinants of the stunting of children under two years old in Indonesia: A multilevel analysis of the 2013 Indonesia basic health survey. Nutrients. 2019;11(5):1106. https://doi. org/10.3390/nu11051106 PMid:31109058

22. Abeway S, Gebremichael B, Murugan R, Assefa M, Adinew YM Stunting and its determinants among children aged 6-59 Months in Northern Ethiopia: A cross-sectional study. J Nutr Metab. 2018;2018:1078480. https://doi.org/10.1155/2018/1078480 PMid:30046469

23. Budiastutik I, Nugraheni A. Determinants of stunting in Indonesia: A review article. Int J Healthc Res. 2018;1(1):2620-5580.

24. Rilyani R. Analysis of Factors That are Related to The Event of Diarrhea in Children in Kedaton Health Center of Bandar Lampung City. The Journal of Holistic Healthcare. 2016;10(3):14. https://doi.org/10.33024/jikk.v7i2.2738

25. Dewi NT, Widari D. The Relationship Between Low Birth Weight and Infection Disease withStunting among Children Under Two Years of Age in at Maron Kidul Village Maron Subdistrict in Probolinggo District. Amerta Nutr. 2018;2(4):373. http://dx.doi. org/10.20473/amnt.v2i4.2018.373-381.

26. Indonesia Undang-Undang Republik. Undang-Undang Republik Indonesia Nomor 4 Tahun 1992 Tentang Perumahan dan Permukiman Dengan. Undang-Undang Republik Indonesia Nomor 4 Tahun 1992 Tentang Perumahan dan Permukiman; 1992. p. 16. https://doi.org/10.31219/osf.io/8e6an

27. Aisah S, Ngaisyah RD, Rahmuniyati ME. Personal hygiene and environmental sanitation are related to the incidence of stunting in Wukirsari village, Cangkringan sub-district. Prosiding Semin Nasional Multidisiplin IImu. 2019;1(2):49-55.

28. Aguayo VM, Nair R, Badgaiyan N, Krishna V. Determinants of stunting and poor linear growth in children under 2 years of age in India: An in-depth analysis of Maharashtra's comprehensive nutrition survey. Matern Child Nutr. 2016;12 Suppl 1:121-40. https://doi.org/10.1111/mcn.12259 PMid:27187911

29. Angelina $\mathrm{C}$, Perdana AA, Humairoh $\mathrm{H}$. Incidence of Stunting Factors for Children Aged 6-23 Months in Lampung Province. J Dunia Kesmas. 2019;7(3):212-4. https://doi.org/10.33024/jdk. v7i3.507. 